\title{
Preliminary study for implementation of voluntary delivery points of expanded polystyrene: a case in southern Brazil
}

\author{
Jaqueline Carneiro Kerber" (D), Henrique Rogério Antunes de Souza Júnior ${ }^{\mathrm{a}}$ (1), \\ Maria Eliza Nagel Hassemera (D), Marina Bouzon ${ }^{\mathrm{a}}$ (D) \\ ${ }^{a}$ Universidade Federal de Santa Catarina, Florianópolis, SC, Brasil \\ *jaqueckerber@gmail.com
}

\begin{abstract}
Paper aims: The purpose of the study is to present a proposal for implementation of Voluntary Delivery Points (VDP) of expanded polystyrene (EPS) in Florianópolis city, Brazil.

Originality: Transportation, uncertainty of financial return, and lack of population's awareness are barriers for EPS recycling. This paper seeks to overcome these difficulties to give a better destination for EPS other than landfill. A method is proposed for the implementation of VDP to receive this type of waste. As far as the authors know, no previous research has proposed this analysis for Styrofoam ${ }^{\circledR} \mathrm{RL}$.

Research method: The research method consists of a survey application with the population and spatial analysis using heat maps of the public equipment on $\mathrm{QGIS}^{\circledR}$ software.

Main findings: It was possible to verify the generation capability of EPS waste in Florianópolis, the lack of population's awareness about EPS recycling, and suitable points for the implementation of VDP to aid in the RL.

Implications for theory and practice: This paper seeks to encourage researchers and practitioners to develop solutions for EPS RL. The main contribution of this article is presenting a practical alternative method that aims to overcome one of the main barriers of EPS RL, which is low-density waste transportation, dealing with consumer's responsibility for the waste generated, their awareness on the issue and their active contribution to a proper destination of EPS waste.
\end{abstract}

\section{Keywords}

Urban solid waste management. Reverse logistics. Spatial analysis.

How to cite this article: Kerber, J. C., Souza Júnior, H. R. A., Hassemer, M. E. N., \& Bouzon, M. (2020). Preliminary study for implementation of voluntary delivery points of expanded polystyrene: a case in southern Brazil. Production, 30, e20190069. https://doi.org/10.1590/0103-6513.20190069.

Received: June 30, 2019; Accepted: Mar. 24, 2020.

\section{Introduction}

Expanded Polystyrene (EPS), commonly known by its trade name Styrofoam ${ }^{\circledR}$, holds many characteristics that make it a valuable product, such as excellent resistance for compression, traction, and bending, which guarantee the integrity of goods during transportation, and capacity of maintaining temperature. Despite EPS advantages and its recyclability, reverse logistics (RL) of this material is not economically attractive for those who produce and commercialize EPS due to its extremely low density, which ends up increasing the price of transportation (Sellitto, 2018). However, EPS deserves more attention because of its high usage and the negative environmental impacts of the incorrect destination of its waste (Gomes et al., 2016).

The RL is an arm of business logistics and has by definition the aim to recapture product value or give it a proper destination through an efficient and economically viable process of planning, implementing and controlling of raw material, processes, finished goods and information flow from the point of consumption to 
the point of origin (Rogers \& Tibben-Lembke, 1999; Moraes et al., 2014; Oliveira Neto et al., 2018). The Solid Waste National Police in Brazil (PNRS, a Portuguese abbreviation for Política Nacional de Resíduos Sólidos) establishes six types of residue obliged to go through a process of RL and leaves open for the possibility of sectoral agreements to happen, which enable to extend this obligation to other types of residue (Brasil, 2010). Mangla et al. (2016) identified success factors related to the implementation of RL in a productive process, among those is relevant to cite governmental laws, tax incentive policies, shared responsibility extended to the producer, financial opportunities, the role and support of stakeholders, and consumer's environmental awareness. The barriers of RL are in accord with the success factors. Some examples are difficulties presented by the members of the supply chain, fees of the process, uncertainties related to economic issues, misinformation about RL and its benefits, and lack of incentive policies (Bouzon et al., 2016, 2018).

Proper management of the RL could reduce not only costs but also increase profits (Rogers \& Tibben-Lembke, 2001). There are methods to overcome the barriers mentioned above and to apply RL to various products, such as purchasing of used products or package and implementation of waste delivery points, encouraging the participation of recyclable and reusable waste collectors' associations (Instituto Brasileiro de Administração Municipal, 2012).

This paper aims to present a proposal for the implementation of Voluntary Delivery Points (VDP) of EPS in Florianópolis, Santa Catarina State, Brazil. To this end, the generation capacity of EPS waste was analyzed, the interest and knowledge of the population about recycling were identified, and the best points for VDP's implementation were defined. The article is organized as followed. The next section brings a literature review on the main topics of this work, EPS, waste collection through VDP, and spatial analysis in urban solid waste management. Section 3 explains the research methods used. Section 4 addresses the research results, and Section 5 brings the discussion of the main findings. Lastly, Section 6 concludes the work with final considerations, limitations of the research, and suggestions for future research on the subject.

\section{Literature review}

\subsection{Expanded polystyrene}

EPS consists of $98 \%$ air and 2\% polystyrene. Due to its resistance to compression, bending and traction, and its flow under compression, according to Almeida et al. (2012), the use of large amounts of EPS can be found from agriculture to building constructions. It is also employed as part of the packaging to improve the protection of electronic products and house appliances, and storage of food, beverages, and some drugs.

EPS production causes few harms to the environment: the use of water is low because it is reused many times during manufacturing, and solid waste generation is minimal, and, in general, it is reintroduced in the process of production. EPS is entirely recyclable and can be recycled many times since the mechanical properties are preserved as in its raw material phase. However, part of the population is poorly informed about EPS recyclability, which leads to its disposal as conventional waste. Therefore, considering the barriers above of its recycling, it generates negative impacts to the environment, since EPS breaks into microplastics when discarded into the environment, and it has the capacity of absorbing toxic composts, such as agrochemicals and heavy metals (Gomes et al., 2016).

One of the main barriers to EPS recycling is its transportation. Due to its low density when compared to other recyclable residues, the space occupied by EPS is too high for the weight that is carried, which increases the transportation costs for industries and municipalities. This condition makes the RL of EPS financially uninteresting, and it is even worse when the taxes are high. Therefore, Styrofoam ${ }^{\circledR}$ waste has become an environmental issue, since the disposal of this material in landfill is not ideal. Beyond the length of time that it takes to deteriorate once in a landfill and the negative impacts of it in nature, EPS takes much space out of landfills, leading to its lifespan diminishment and to the need for looking for more places to install new landfills.

\subsection{Selective waste collection using VDP}

According to Roviriego (2005), the purpose of selective waste collection is the separation of discarded materials in the generating source, separating them by type or group of material. The author explains the necessity of a market for this kind of product and of the population's active participation in the collection process. VDP is one method of selective waste collection, which are containers made of resistant material located in different spots of a city, where the generators discard their recyclable waste by going to one of these containers and properly discarding the residue (Alvarenga, 2015, p. 49). This solution is also pointed out by Arenhardt et al. (2018) as a means to reduce internal fragilities of municipal waste collection, additionally with the creation of recycler's associations that promote the right segregation and destination of residues. 
As stated by Ferri et al. (2015), when the place of waste disposition is centralized, there is an increase in volume and quantity, which can make the commercialization of the recyclable residue easier than in a decentralized system. The author also argues that with a centralized system, recycler's association can increase the variety of material with the commercial potential of recyclability and their insertion on the market, which improves the association's profitability. As more waste collection containers are distributed in a community, and as more people get educated and informed about recycling, more plastic inevitably will be recycled over the years (Fletcher \& Mackay, 1996).

VDP is a way of receiving waste generated and it can be used as a mean of separating the received material, enabling a differentiated waste collection that contributes to proper waste disposal (Paz et al., 2018). Nowadays, the city of Florianópolis has implemented VDP to collect only glass packaging. According to COMCAP (a Portuguese abbreviation for Companhia de Melhoramentos da Capital, 2013), which is the company responsible for the collection of waste in Florianópolis city, the potential for glass waste collection is 3,700 ton $\left(8,300 \mathrm{~m}^{3}\right)$ per year, which represents a total of 112 thousand of Reais if this waste goes to a landfill and lost of 57.3 thousand Reais per year of profits. The system covers capture, collection, sorting, beneficiation, and commercialization of glass. These VDP are stationary containers with a capacity of 2,500 liters and are installed in spots of high flow of people.

Some cities from the basin of Alto Tietê, in the state of São Paulo, also provide VDP to the population to give away waste like construction waste, kitchen oil, tires, lamps, batteries, and others (Klein et al., 2018). In Buenos Aires, Argentina, EPS waste is brought by the population to the so-called "Green Mobile Center" that corresponds to the VDP. Those centers receive different kinds of recyclable materials, such as paper and paperboard, glass, metals, and plastics, and it opens on specific days and hours. Besides, people who bring their residues to these points are received by a staff member who helps them with the waste's destination. According to data from the City Government of Buenos Aires (2016), the delivery of recyclables in the green centers increased by 58\% in 2016 compared to 2015.

In Ponta Grossa city, Paraná State, Brazil, there are already VDP to delivery EPS throughout the city, which is an initiative of the Union of Private Teaching Establishments of the State of Paraná (SINEPE/PR, a Portuguese abbreviation for Sindicato dos Estabelecimentos Particulares de Ensino do Estado do Paraná) and of MEIWA (a company producer of EPS packaging). The project is called "Friends of Nature" and besides the implementation of VDP, they stimulate teenagers and, consequently, adults to recycle EPS through workshops, seminars e lectures in high schools.

In 2016 in São Paulo city, a Monitored Voluntary Delivery Point (M-VDP) was installed for EPS packaging by the project "Recycle Styrofoam ${ }^{\circledR}$ ". All the material accumulated is commercialized and transformed into new products. This project increases the profits of those who work with recycling and promotes awareness about EPS recycling possibility and the importance of giving a proper destination to this kind of waste.

\subsection{Spatial analysis in urban solid waste management}

One of the main issues to be analyzed during the planning and implementation of an urban solid waste management system is the economic aspect. According to Ornelas (2011), in this context, spatial analysis methods represent essential tools to manage spatially distributed information, such as areas for the implementation of landfills, waste collection routes and sizing of the fleet, places to install transshipment, sorting and recycling units and others. Paz et al. (2018) also made use of spatial analysis through Geographic Information System (GIS) to determine the best location of VDP for the collection of construction waste.

According to Santos et al. (2012), one of the most common maps for spatial analysis are those that use points to represent the studied phenomenon, and an allocation analysis of their distribution may be the first step for exploratory analysis. The Kernel estimator is an interpolation tool that enables the estimation of the intensity of an event in an area, even in those where the process has generated no real occurrence (Santos et al., 2012). As stated by Câmara \& Carvalho $(2004$, p. 2), Kernel estimator is a bi-dimensional function that proceeds to the accounting of all the points inside a region of influence, weighting them by the distance between them and the place of interest.

According to Câmara \& Carvalho (2004), assuming that $u_{1}, u_{2}, \ldots, u_{n}$ are locations of $n$ observed events in the region $A$ and that $u$ represents a generic location, whose value is to be estimated. The bi-dimensional function of the Kernel estimator is calculated from $m$ events $\left\{u_{p}, \ldots, u_{i+m-1}\right\}$ in a range of $\tau$ size around $u$ and the distance $d$ between the position 1 and the $i$-th sample, from the function described in (1):

$$
\lambda_{\tau}(u)=\frac{1}{\tau^{2}} \sum_{i=1}^{n} k\left(\frac{d\left(u_{i}, u\right)}{\tau}\right), d\left(u_{i}, u\right) \leq \tau
$$


where $\lambda$ is the function of intensity defined by a radius of influence $\tau$ from the analyzed point; and $k$ is a specific interpolation function that determines the surface of the influence of $\tau$.

The choice of the radius of influence needs to be well weighted because a radius too small will generate a very discontinuous surface and has a tendency to create peaks centered $u$; if the radius is too high, the surface will end up too smooth (Câmara \& Carvalho, 2004; Ornelas, 2011).

\section{Methods}

The research delineated steps are described in Figure 1. The first step consists of the definition of the objectives of the research, in the construction of theoretical ground, and the choice of the research methods, employing a literature review and search of case studies of VDP implementation to collect EPS in other cities. The application of the method happened in the second step, which covered a characterization of the area of study, the application of the survey, and the spatial analysis for VDP allocation. Finally, in the third step, the results were analyzed, which consisted of an estimation of the waste generation of EPS in Florianópolis city, the awareness, and interest of the population of Florianópolis about the recycling of EPS and the ideal points in the city to install the VDP.

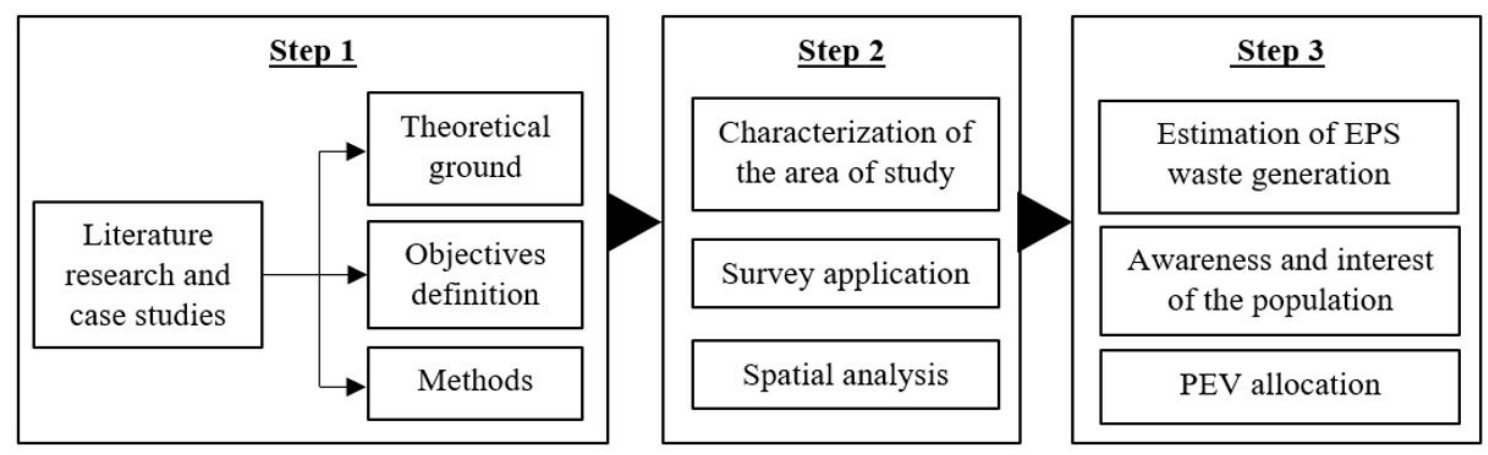

Figure 1. Steps for the development of the study. VDP - Voluntary Delivery Point.

\subsection{Characterization of the area of study}

The area of study contemplates the city of Florianópolis, Santa Catarina State, Brazil, with a population of 421,240 inhabitants (Instituto Brasileiro de Geografia e Estatística, 2016), from which 96\% live in urban areas. According to IBGE, approximately $93 \%$ of the generated waste is collected directly by the waste collection services, $6 \%$ are placed in containers proper for waste collection, and 1\% are either burned, buried by the generator in their property, or given other types of destinations.

\subsection{Application of survey}

In the first step of the present work, a survey was applied to obtain a parameter of the consumption of EPS packaging and the population awareness and interest in EPS recycling. The survey focused on the population of Florianópolis city, but it was not restricted to them since the respondents could live in cities nearby but come to Florianópolis to work or leisure. The survey was applied in two ways, an online version, and a physical version.

It is important to highlight that the collected sample tried to include different social realities; however, it cannot be considered as probabilistic, because the sampling was made by convenience. Although this method was chosen, justified by time and resources, a confidence level of 95\% was determined for the sampling and, based on Equation 2 (Levine et al., 1997) to determine the size sample (n), it has a sampling error of 10\%, considered acceptable in the conditions presented.

$$
n=\frac{Z^{2} \times p \times q}{e^{2}}
$$

where $Z$ is the level of confidence; $p$ is the expected proportion; and e the sampling error. $q$ corresponds to the complement proportion expected $p$, being $q=1-p$. 
Since there is no prior knowledge of the right proportion of the population, $p$ is considered 0.5 (Levine et al., 1997). Nevertheless, the results on the generation of EPS waste were proportionally projected to the population of Florianópolis city. This decision intended to present the generation potential of this type of waste and encourage the discussion about the subject.

In the first part of the survey, the respondent answered questions about their consumption habits towards EPS. The second part consisted of questions about the awareness of the population about the capacity of EPS being recycled and their interest in giving this residue a proper destination since they knew at that moment that EPS is recyclable. The last question of this part was done only to those who that either would take the waste of EPS to a VDP only when it would be practical and not interfere in their daily activities, or would not take the EPS residue to a VDP because they believed it was not practical and that they did not see any advantages in doing so. This last question aimed to verify if, even with a little more information about the barriers of EPS recycling and the consequences related to not doing it, people would change their minds or not about the possibility of taking their EPS waste to a VDP.

\subsection{Allocation of VDP for EPS}

The method adopted by Ornelas (2011) was used to determine the ideal spots for the VDP implementation. The software used to aid in the spatial analysis was QGis 2.18, free software of Geographical Information System (GIS), and the definition of the points was based on a set of data obtained from this spatial analysis. Firstly, public equipment was identified, defined by Ornelas (2011) as public places, for example, schools and parks, which are natural areas where VDP could be implemented, due to the high circulation of people; supermarkets were also considered. The compilation of these places in the city of Florianópolis was done manually using lists available on the internet, such as online telephone books. The locations of the compiled equipment were included manually in the QGis software in order to be assessed with the Heat Map tool, also known as Kernel's Map, which was applied to determine the density of these places in the municipal perimeter of Florianópolis. By using this tool, a buffer of $200 \mathrm{~m}$ was used to define the radius, which would be the maximum distance a person would be willing to walk to place their recyclable residue in a VDP, according to Ornelas (2011). Five qualitative levels were established based on the density of public equipment and their influence area in the city. The levels are very high density, high density, average density, low density, and very low density of public equipment.

Secondly, maps of the population density of Florianópolis were created. Using the data of the number of inhabitants by census sector from the last Demographic Census of 2010 and the shapefile data of the census sectors provided by IBGE (a Portuguese abbreviation for Brazilian Institute of Geography and Statistics), it was possible to define the populational density of each census sector. Five qualitative levels were also defined to analyze these maps about their suitability for receiving a VDP based on the density of population in those sectors: very high suitability, high suitability, average suitability, low suitability, and very low suitability.

Thirdly, the main roads of Florianópolis were included in the maps. This information was added justified by the need to verify the points where would have more transition of vehicles since those who utilize a private vehicle for daily mobility would have the opportunity to leave their recycled waste in a VDP while going to work, for example. The roads defined as main routes are regarding data about intercity roads available on shapefile data of the Digital Topographic Map Collection of Santa Catarina State (Empresa de Pesquisa Agropecuária e Extensão Rural de Santa Catarina, 2004).

Finally, a spatial analysis was performed and, then, the spots that could present higher utility potential for the implementation of VDP were defined. In a first analysis, areas of a higher number of public equipment and higher populational density, which were areas of high suitability for VDP implementation, were chosen. Then, this first result was refined by using the information on the main roads of the city.

\section{Results}

\subsection{Survey}

A total of 71 people answered the online questionnaire, and 72 answered the physical version, making it a total of 143 respondents. From this number, 122 respondents live in the conurbation area of Florianópolis, which include the cities of São José, Biguaçu, and Palhoça. The answers from these 122 respondents were considered for assessment, justified by the fact that many people that live in the other cities of the conurbation area work in Florianópolis. Due to this condition, part of the waste generated by them is absorbed by the waste collection 
and destination system of Florianópolis and, consequently, would be collected by the proposed EPS VDP. Therefore, the data gathered from 122 respondents were used to represent the habits of EPS consumption for the population of Florianópolis. The answers from the other respondents were discarded. According to IBGE, the estimated population of Florianópolis was 477,798 inhabitants in 2016. In order to promote an initial exploratory study on the EPS waste issue in the conurbation area of Florianópolis and start a discussion on the topic, this research performed an evaluation of the potential of EPS waste generated in the area of study by making an extrapolation of the data acquired in the survey. A complete version of the survey is presented in Appendix A.

Table 1 presents the first part of the survey. In order to estimate the total weight of the waste, it was considered that one cup of EPS of $200 \mathrm{~mL}$, one EPS tray of $23 \mathrm{~cm} \times 33 \mathrm{~cm} \times 50 \mathrm{~cm}$, and one round EPS vessel for meal of $66 \mathrm{~cm} \times 37 \mathrm{~cm} \times 37 \mathrm{~cm}$ weight on average $2.5 \mathrm{~g}, 0.74 \mathrm{~g}$ and $1.21 \mathrm{~g}$ respectively. The results obtained from the survey were considered directly proportional to the total of inhabitants. Based on this statement, the value of waste generation was estimated for each one of the packaging types analyzed in the survey. The quantities are, approximately, 834 thousand of trays commercialized with food, 332.9 thousand

Table 1. Results of the first part of the survey.

\section{FIRST PART OF THE OUESTIONNAIRE}

\begin{tabular}{|c|c|c|c|c|c|c|}
\hline \multicolumn{7}{|c|}{ How many food products with Styrofoam ${ }^{\otimes}$ packaging do you consume per week? (Fruits, greenery, meat) } \\
\hline Answer & $\begin{array}{l}\text { Quantity } \\
\text { considered for } \\
\text { assessment }\end{array}$ & $\begin{array}{c}\text { Only inhabitants } \\
\text { of the } \\
\text { conurbation area } \\
\text { of Florianópolis }\end{array}$ & $\begin{array}{l}\text { Percentage of the } \\
\text { respondents }(\%)\end{array}$ & $\begin{array}{l}\text { Estimated } \\
\text { population }\end{array}$ & $\begin{array}{l}\text { Consumed } \\
\text { quantity by } \\
\text { the estimated } \\
\text { population }\end{array}$ & Total weight $(\mathrm{kg})$ \\
\hline 1 don't consume. & 0 & 40 & 32.79 & 156,655 & 0 & 0 \\
\hline 1 to 3. & 2 & 69 & 56.56 & 270,230 & 540,460 & 399.94 \\
\hline 4 to 6. & 5 & 8 & 6.56 & 31,331 & 156,655 & 115.92 \\
\hline 7 or more. & 7 & 5 & 4.1 & 19,582 & 137,074 & 101.43 \\
\hline & & & \multicolumn{2}{|c|}{ TOTAL } & 834,189 & 617.3 \\
\hline \multicolumn{7}{|c|}{ How many Styrofoam ${ }^{\circledR}$ cups do you use per week? (For coffee, tea, juice) } \\
\hline Answer & $\begin{array}{c}\text { Quantity } \\
\text { considered for } \\
\text { assessment }\end{array}$ & $\begin{array}{l}\text { Only inhabitants } \\
\text { of the } \\
\text { conurbation area } \\
\text { of Florianópolis }\end{array}$ & $\begin{array}{l}\text { Percentage of the } \\
\text { respondents }(\%)\end{array}$ & $\begin{array}{l}\text { Estimated } \\
\text { population }\end{array}$ & $\begin{array}{l}\text { Consumed } \\
\text { quantity by } \\
\text { the estimated } \\
\text { population }\end{array}$ & Total weight $(\mathrm{kg})$ \\
\hline 1 don't consume. & 0 & 88 & 72.13 & 344,641 & 0 & 0 \\
\hline 1 to 3. & 2 & 29 & 23.77 & 113,575 & 227,150 & 567.88 \\
\hline 4 to 6 . & 5 & 4 & 3.28 & 15,666 & 78,330 & 195.83 \\
\hline \multirow[t]{2}{*}{7 or more. } & 7 & 1 & 0.82 & 3,916 & 27,412 & 68.53 \\
\hline & & & \multicolumn{2}{|c|}{ TOTAL } & 332,892 & 832.23 \\
\hline \multicolumn{7}{|c|}{ How many Styrofoam ${ }^{\circledR}$ vessels do you use to store meal per week? } \\
\hline Answer & $\begin{array}{l}\text { Quantity } \\
\text { considered for } \\
\text { assessment }\end{array}$ & $\begin{array}{l}\text { Only inhabitants } \\
\text { of the } \\
\text { conurbation area } \\
\text { of Florianópolis }\end{array}$ & $\begin{array}{l}\text { Percentage of the } \\
\text { respondents }(\%)\end{array}$ & $\begin{array}{l}\text { Estimated } \\
\text { population }\end{array}$ & $\begin{array}{l}\text { Consumed } \\
\text { quantity by } \\
\text { the estimated } \\
\text { population }\end{array}$ & Total weight $(\mathrm{kg})$ \\
\hline 1 don't consume. & 0 & 81 & 66.39 & 317,227 & 0 & 0 \\
\hline 1 to 3. & 2 & 29 & 23.77 & 113,575 & 227,150 & 274.85 \\
\hline 4 to 6. & 5 & 9 & 7.38 & 35,247 & 176,235 & 213.24 \\
\hline 7 or more. & 7 & 3 & 2.46 & 11,749 & 82,243 & 99.51 \\
\hline
\end{tabular}

EPS cups and 485.6 thousand vessels to store meal, which represent the following total weight, respectively: $617.3 \mathrm{~kg}, 832.23 \mathrm{~kg}$, and $587.61 \mathrm{~kg}$. The weekly potential of waste domestically generated is 2,037.14 kg. Taking into consideration that the analysis does not consider EPS packaging generated in other situations, such as those used to protect household appliances or electronics, the quantity of waste generated of EPS is higher than the one calculated.

The results of the second part of the survey are presented in Table 2. With an estimated value of 2,037.14 kg of EPS waste generation calculated in the first part and the percentages of answers from the second part, it is possible to estimate values for EPS recycling by extrapolating the results of the survey for the population of Florianópolis city. Employing the extrapolation, it is assumed that $1,185.55 \mathrm{~kg}$ of EPS waste domestically generated is recycled per week (considering $801.5 \mathrm{~kg}$ and $384.05 \mathrm{~kg}$ for the first two answers for the first question, in which the respondents state that they recycle EPS), corresponding to approximately $58 \%$ of what estimated 
Table 2. Results of the second part of the survey.

SECOND PART OF THE QUESTIONNAIRE

Do you recycle the Styrofoam ${ }^{\circledast}$ packaging of the products that you consume?

\begin{tabular}{lcccc}
\hline & $\begin{array}{c}\text { Only } \\
\text { inhabitants of } \\
\text { the conurbation } \\
\text { are of } \\
\text { Florianópolis }\end{array}$ & $\begin{array}{c}\text { Percentage of } \\
\text { the respondents } \\
(\%)\end{array}$ & $\begin{array}{c}\text { Estimated } \\
\text { population }\end{array}$ & $\begin{array}{c}\text { Total weight } \\
(\mathrm{kg})\end{array}$ \\
\hline Yes, 1 recycle all the EPS packaging. & 48 & 39.34 & 187,986 & 801.5 \\
Yes, except the ones used to pack meat, because they are contaminated. & 23 & 18.85 & 90,077 & $384.05^{*}$ \\
No, but 1 know it can be recycled. & 31 & 25.41 & 121,408 & 517.63 \\
No, 1 did not know that EPS is recyclable & 20 & 16.39 & 78,328 & 333.96 \\
\hline
\end{tabular}

If there was the possibility to delivery the Styrofoam ${ }^{\circledR}$ waste in a specific place, such as a Voluntary Delivery Point (VDP), would you do it?

\begin{tabular}{|c|c|c|c|c|}
\hline & $\begin{array}{c}\text { Only } \\
\text { inhabitants of } \\
\text { the conurbation } \\
\text { are of } \\
\text { Florianópolis }\end{array}$ & $\begin{array}{l}\text { Percentage of } \\
\text { the respondents } \\
(\%)\end{array}$ & $\begin{array}{l}\text { Estimated } \\
\text { population }\end{array}$ & $\begin{array}{l}\text { Total weight } \\
\quad(\mathrm{kg})\end{array}$ \\
\hline Yes, always. & 34 & 27.87 & 133,157 & 567.73 \\
\hline $\begin{array}{l}\text { Yes, whenever it would be possible, otherwise, } 1 \text { would discard it with } \\
\text { the recyclables at home. }\end{array}$ & 74 & 60.66 & 289,812 & $1,235.64$ \\
\hline No, because 1 do not believe it would be practical. & 14 & 11.48 & 54,829 & 233.77 \\
\hline No, because 1 do not see advantages in doing so. & 0 & 0 & 0 & 0 \\
\hline
\end{tabular}

Did you know that around $98 \%$ of Styrofoam ${ }^{\circledast}$ is air? The main barrier of its recycling is transportation, and it occupies a significant space
until it is viable for recycling it. However, most of the time, it is discarded with regular waste and ends up in landfills. There EPS waste
occupies too much space, compromising the lifespan of the landfill. One simple action could help to reduce the impacts caused by EPS
when it arrives in the environment, to transform it into new products, such as bricks and skirtings, or even become a packaging again. This
information makes you rethink about delivering Styrofoam ${ }^{\circledast}$ waste in a specific place, like a VDP, for example?

\begin{tabular}{lcccc}
\hline & $\begin{array}{c}\text { Only } \\
\text { inhabitants of } \\
\text { the conurbation } \\
\text { are of } \\
\text { Florianópolis }\end{array}$ & $\begin{array}{c}\text { Percentage of } \\
\text { the respondents } \\
(\%)\end{array}$ & $\begin{array}{c}\text { Estimated } \\
\text { population }\end{array}$ & $\begin{array}{c}\text { Total weight } \\
(\mathrm{kg})\end{array}$ \\
\hline Yes, 1 would deliver the Styrofoam & & & & \\
l am still not sure, but this information made me rethink about it. & 40 & 32.79 & 156,655 & 667.91 \\
No, this information did not make me change my mind. & 45 & 36.89 & 176,237 & 751.4 \\
\hline
\end{tabular}

as generated. $851.59 \mathrm{~kg}$ of EPS per week is not recycled, which was justified by the fact the respondents living location does not have a waste collection service, or recycling is not a habit, and/or lack of awareness.

With the data gathered in the second question, $567.73 \mathrm{~kg}$ of EPS residue would be delivered per week in a VDP, and 1,235.64 $\mathrm{kg}$ would be deposited in a VDP or would be recycled through the selective waste collection. The difference between these two possibilities is that the recycling of EPS would be guaranteed if the residue was brought to a VDP, and the recycling could not happen in case of it going to the selective waste collection system. However, it should be noted a possible increase of $617.82 \mathrm{~kg}$ in the EPS residue that would be recycled with the implementation of VDP in Florianópolis, leading to growth to $88.5 \%$ in its recycling. It is also possible to analyze that $233.77 \mathrm{~kg}$ per week would not be recycled.

The third question explains the recycling of EPS waste broadly to the respondent. After presenting the barriers, from the amount of $1,469.41 \mathrm{~kg}$ per week that could not be recycled (233.77 kg actually would not be recycled and $1,235.64 \mathrm{~kg}$ that would end up in a VDP or the selective waste collection) $667.91 \mathrm{~kg}$ would be destined to a VDP, what could guarantee the recycling of EPS. This scenario would result in an amount of $1,235.64 \mathrm{~kg}$ of EPS residue being discarded into VDP. This value corresponds to the number stipulated in the second question, so it maintains the value of $88.52 \%$ of the recycling of the generated EPS waste.

\subsection{Spatial analysis for the implementation of VDP for EPS}

After determining the location of the public equipment, acquiring populational data of the census sectors, and locating the main roads of Florianópolis, it was possible to develop maps that would aid in the definition of suitable points to implement VDP for EPS waste delivery. For better visualization, the city was divided into four regions: center (Figure 2), north (Figure 3), south (Figure 4), and the mainland (Figure 5). 


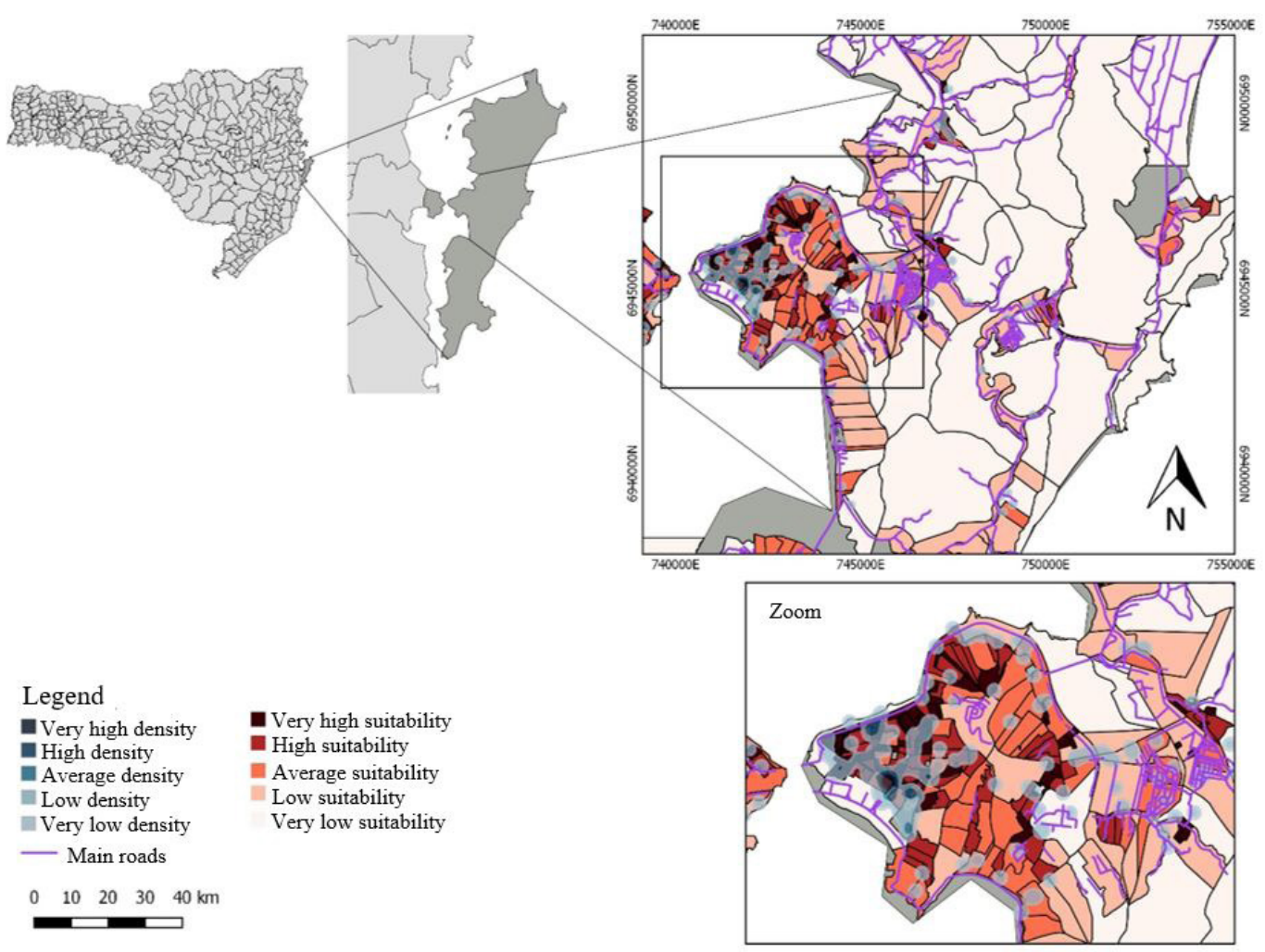

Figure 2. Density of inhabitants in the census sectors (red shades) and public equipment (blue shades) and main roads, central region.

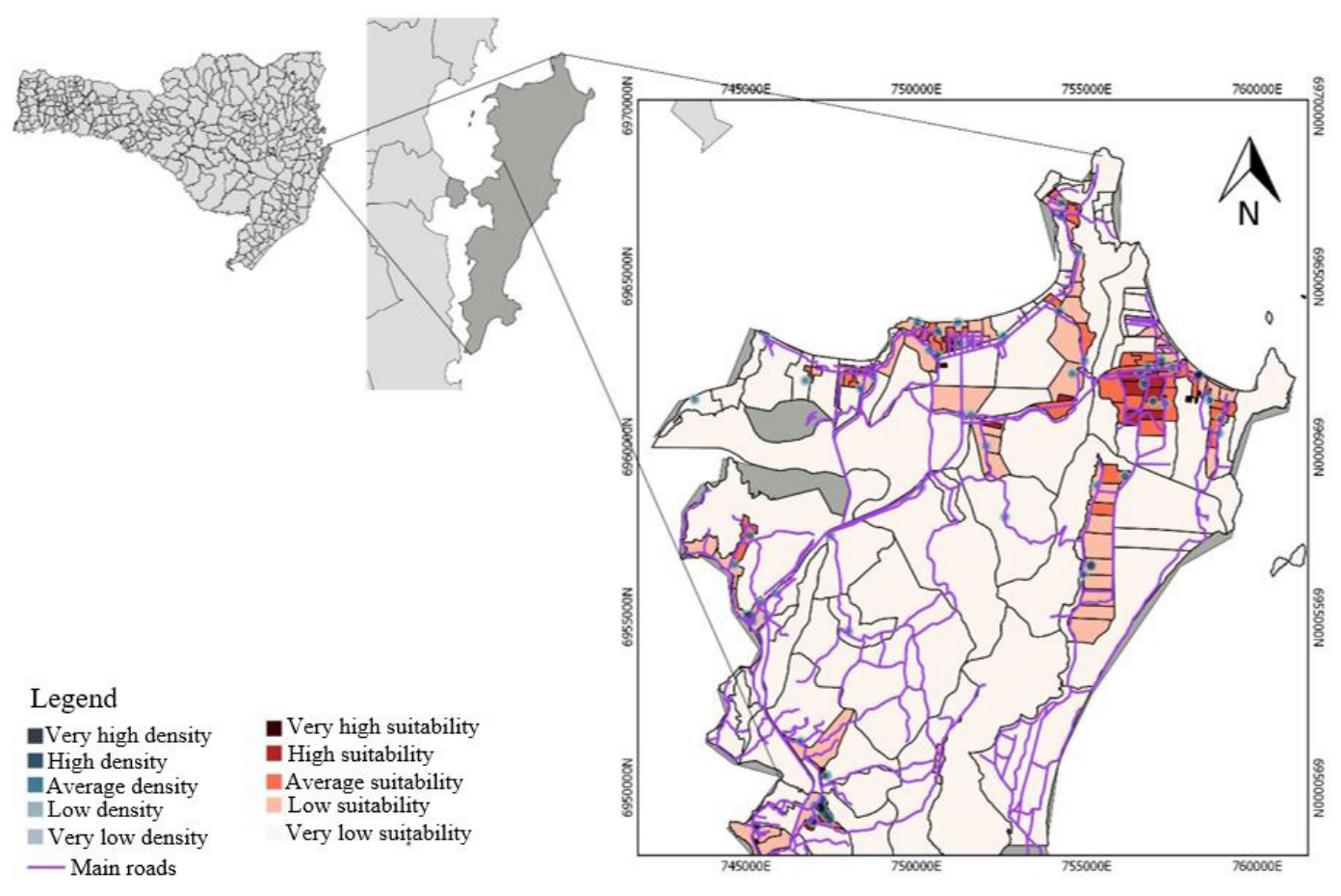

Figure 3. Density of inhabitants in the census sectors (red shades) and public equipment (blue shades) and main roads, north region. 
בo

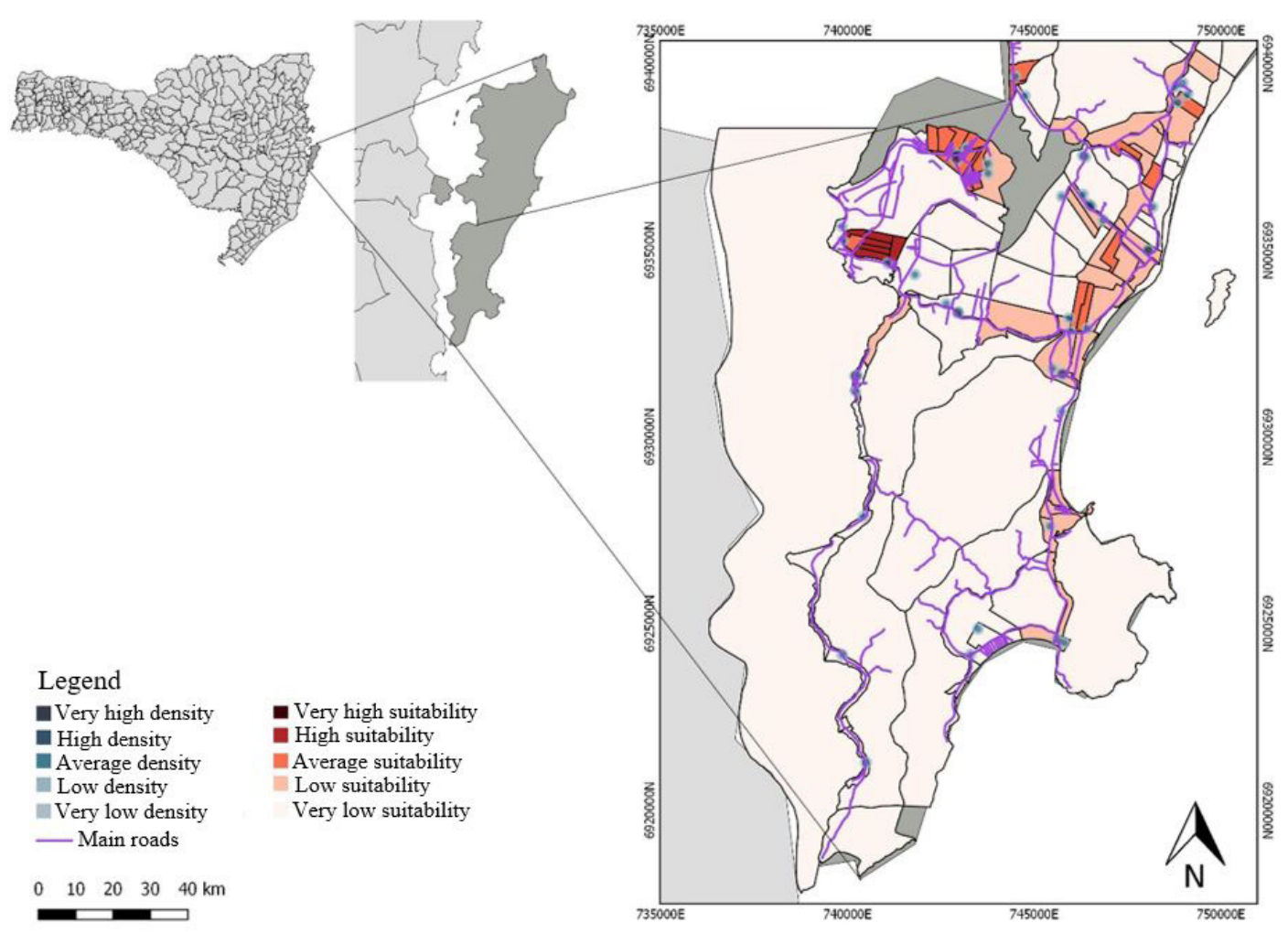

Figure 4. Density of inhabitants in the census sectors (red shades) and public equipment (blue shades) and main roads, south region.

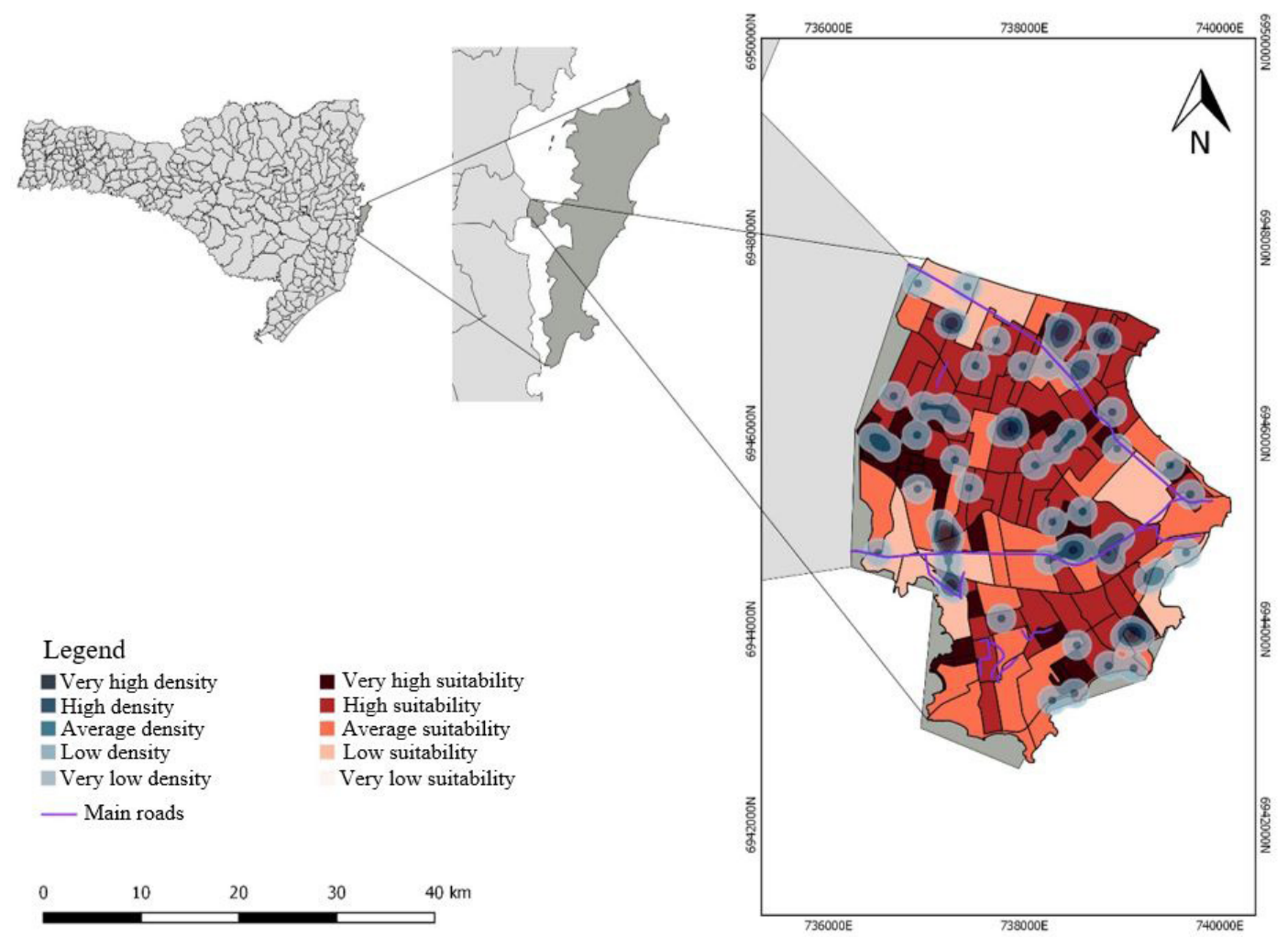

Figure 5. Density of inhabitants in the census sectors (red shades) and public equipment (blue shades) and main roads, mainland region. 
It is suggested that an action plan for the installation of the VDP operate in three parts:

- First part: VDP installation in areas of very high and high suitability, i.e., very high and high populational density, and points where there are a very high and high density of public equipment.

- Second part: areas between very high and average suitability and points where there are between the very high and average density of public equipment.

- Third part: verify the places where still could present demand for VDP, and that could represent a high potential for EPS waste generation.

For the first part of the action plan, nine points were identified in the mainland, four in the center, one in the north and one in the south. In the second part, it was found four points in the mainland, eight in the center, eight in the north, and five in the south (not considering the points already found in the first part).

\section{Discussion}

Means of improving the disposal of waste is an issue addressed by researchers and decision-makers, due to the increasing pressure of the population and Governmental agencies. The adoption of VDP is a possible solution, which was the central issue tackled by this paper for EPS disposal in the city of Florianópolis, Santa Catarina State, Brazil. Different authors also proposed this kind of solution, but for different kinds of waste.

Paz et al. (2018) proposed to install VDP in Recife city, Brazil, to provide an option for the collection of construction and demolition waste. Despite the differences in characteristics between this type of waste with expanded polystyrene and in the chosen method, the variables used by these authors to determine the location of VDP are similar to the ones treated here. In both works, physical and socio-environmental aspects were analyzed, specific categories like location, accessibility, urban mobility, and urban infrastructure. Ornelas (2011) suggested using urban infrastructure to determine the best locations for VDP. These places, referred by him as public equipment, served as parameters for the spatial analysis of the present work.

Not only it is necessary to provide means to contribute to the recycling process, but there is also the need to educate the population about it. As mentioned previously, municipalities are already implementing VDP, and, at the same time, they endeavor to instruct, inform, and educate the community about recycling. This study identified misinformation about the recyclability of EPS, and it is believed that the lack of knowledge about the subject may be extended to different materials and cities.

As pointed out by Bouzon et al. $(2016,2018)$, some of the barriers of RL are connected to the awareness of the population and of the channels involved in the supply chain. Gomes et al. (2016) indicated that this type of barrier also exists in the RL of EPS, which was reinforced by the results of the survey applied in this work. Arenhardt et al. (2018) stated that one of the actions that could contribute to recycling is to disseminate, inform and raise awareness of the population about the implications of not giving the proper destination to the residue. Despite the different kinds of waste analyzed by the authors, the situation posited above can easily be applied to other types of waste, including EPS.

Thus, this paper has a twofold contribution to EPS RL. On one hand, it presents a practical alternative method, which includes a survey application and a spatial analysis using heat maps of the public equipment on QGIS ${ }^{\circledR}$ software. On the other hand, it tackles one of the main barriers to implementing EPS RL, which is low-density waste transportation. For this last matter, the solution methodology deals with consumer's responsibility for the waste generated, their awareness on the issue, and their active contribution to a proper destination of EPS waste.

\section{Conclusion}

With the results of the survey, it was possible to conclude that the conurbation area in which Florianópolis city is inserted has the potential to recycle EPS, based on the amount of waste raised by this study. With these results, it is noteworthy that most of the respondents know that EPS is recyclable. However, they are unaware of the conditions in which the EPS waste should be to be recycled, characterizing a lack of information of the population about the correct discard of this post-consumer waste.

This work proposed a VDP implementation plan in the city. In the first part of the plan, 15 VDP are to be installed, while 25 VDP should be placed in a second phase. Then, in the third part, it is suggested to verify the adherence of the population in delivering EPS voluntarily in these points. If this adoption by the population is little, it would be interesting to reanalyze the places where the VDP is allocated. Due to access easiness, it is crucial that the location of the VDP is near to the main roads of the city. 
One of the limitations of this work relies on the fact that the sample of respondents is not probabilistic, and the data extrapolation, therefore, may have generated uncertainty. Future research should focus on this issue and try to obtain data as near to reality as possible. Besides, in order to provide a more precise VDP implementation plan, it is suggested to perform a study on EPS waste generation capacity, including different types of generation sources of this residue. Finally, another path of research could be the study on vehicle fleet routing for waste collection from VDP and evaluation of the economic aspect of the RL process of EPS.

\section{References}

Almeida, J. E., Logsdon, N. B., \& Jesus, J. M. H. (2012). Painéis de madeira aglomerada produzidos com serragem e poliestireno expandido. Floresta, 42(1), 189-200. http://dx.doi.org/10.5380/rf.v42i1.26317.

Alvarenga, J. C. F. (2015). Gerenciamento de resíduos sólidos urbanos: uma análise da distribuição espacial dos pontos de entrega voluntária de material reciclável em Viçosa/MG. Revista Políticas Públicas \& Cidades, 2, 45-66. Retrieved in 2019, June 30, from http://periodico.revistappc.com/index.php/RPPC/article/view/3

Arenhardt, V., São Pedro Filho, F.., Schalch, W., Deliza, E. E. V., \& Back, R. B. (2018). Integrated waste management technology with focus on the Brazilian Amazon. International Journal of Advanced Engineering Research And Science, 5(3), 121-131. http://dx.doi. org/10.22161/ijaers.5.3.15.

Bouzon, M., Govindan, K., \& Rodriguez, C. M. T. (2018). Evaluating barriers for reverse logistics implementation under a multiple stakeholders' perspective analysis using grey decision making approach. Resources, Conservation and Recycling, 128, 315-335. http:// dx.doi.org/10.1016/j.resconrec.2016.11.022.

Bouzon, M., Govindan, K., Rodriguez, C. M. T., \& Campos, L. M. S. (2016). Identification and analysis of reverse logistics barriers using fuzzy Delphi method and AHP. Resources, Conservation and Recycling, 108, 182-197. http://dx.doi.org/10.1016/j.resconrec.2015.05.021.

Brasil. (2010, August 3). Institui a Política Nacional de Resíduos Sólidos; altera a Lei no 9.605, de 12 de fevereiro de 1998; e dá outras providências (Lei $n^{\circ}$ 12.305, de 2 de agosto de 2010). Diário Oficial da República Federativa do Brasil. Retrieved in 2019, June 30, from http://www.planalto.gov.br/ccivil_03/_ato2007-2010/2010/lei/112305.htm

Buenos Aires. (2016, June 29). Cada vez más vecinos dejan sus reciclables em los Puntos Verdes. Gobierno de la Ciudad Autónoma de Buenos Aires. Retrieved in 2019, June 30, from http://www.buenosaires.gob.ar/noticias/cada-vez-mas-vecinos-dejan-sus-reciclablesen-los-puntos-verdes

Câmara, G., \& Carvalho, M. S. (2004). Análise espacial de eventos. In S. Druck, M. S. Carvalho, G. Câmara \& A. M. V. Monteiro (Eds.), Análise espacial de dados geográficos. Brasília: Embrapa. Retrieved in 2019, June 30, from http://www.dpi.inpe.br/gilberto/livro/analise/

Companhia de Melhoramentos da Capital - COMCAP. (2013). Projeto: coleta seletiva vidro. Florianópolis: COMCAP. Retrieved in 2019, June 30, from http://portal.pmf.sc.gov.br/arquivos/arquivos/pdf/10_12_2014_8.05.39.41a97d90cda7414db617b98ef5783514.pdf

Empresa de Pesquisa Agropecuária e Extensão Rural de Santa Catarina - EPAGRl. (2004). Mapas digitais de Santa Catarina. Florianópolis: Epagri/lBGE. Retrieved in 2019, June 30, from http://ciram.epagri.sc.gov.br/mapoteca/index.jsp

Ferri, G. L., Chaves, G. L. D., \& Ribeiro, G. M. (2015). Análise e localização de centros de armazenamento e triagem de resíduos sólidos urbanos para a rede de logística reversa: um estudo de caso no município de São Mateus, ES. Production, 25(1), 27-42. http:// dx.doi.org/10.1590/S0103-65132014005000014.

Fletcher, B. L., \& Mackay, M. E. (1996). A model of plastics recycling: does recycling reduce the amount of waste? Resources, Conservation and Recycling, 172), 141-151. http://dx.doi.org/10.1016/0921-3449(96)01068-3.

Gomes, A. M., Alves, B. V., \& Bouzon, M. (2016, December). Análise de barreiras para a logística reversa do poliestireno expandido: uma investigação em uma empresa recicladora de EPS no Brasil. In Anais do $18^{\circ}$ Encontro Internacional sobre Gestão Empresarial e Meio Ambiente. São Paulo: FEA-USP.

Instituto Brasileiro de Administração Municipal - IBAM. (2012). Estudo de viabilidade técnica e econômica para implantação da logística reversa por cadeia produtiva: componente produtos e embalagens pós-consumo. Rio de Janeiro: IBAM. Retrieved in 2019, June 30, from http://sinir.gov.br/images/sinir/LOGISTICA_REVERSA/EVTE_PRODUTOS_EMBALAGENS_POS_CONSUMO

Instituto Brasileiro de Geografia e Estatística - IBGE. (2016). Cidades. Retrieved in 2019, June 30, from http://cidades.ibge.gov.br

Klein, F. B., Gonçalves-Dias, S. L. F., \& Jayo, M. (2018). Gestão de resíduos sólidos urbanos nos municípios da Bacia Hidrográfica do Alto Tietê: uma análise sobre o uso de TIC no acesso à informação governamental. Urbe. Revista Brasileira de Gestão Urbana, 10(1), 140-153. http://dx.doi.org/10.1590/2175-3369.010.001.ao10.

Levine, D. M., Berenson, M. L., \& Stephan, D. (1997). Statistics for managers using Microsoft Excel. Upper Saddle River: Prentice Hall.

Mangla, S. K., Govindan, K., \& Luthra, S. (2016). Critical success factors for reverse logistics in Indian industries: a structural model. Journal of Cleaner Production, 129, 608-621. http://dx.doi.org/10.1016/j.jclepro.2016.03.124.

Moraes, D. G. S. V. M., Rocha, T. B., \& Ewald, M. R. (2014). Life cycle assessment of cell phones in Brazil based on two reverse logistics scenarios. Production, 24(4), 735-741. http://dx.doi.org/10.1590/S0103-65132014005000011.

Oliveira Neto, G. C., Ruiz, M. S., Correia, A. J. C., \& Mendes, H. M. R. (2018). Environmental advantages of the reverse logistics: a case study in the batteries collection in Brazil. Production, 28(0), 1-16. http://dx.doi.org/10.1590/0103-6513.20170098.

Ornelas, A. R. (2011). Aplicação de métodos de análise espacial na gestão dos resíduos sólidos urbanos (Dissertação de mestrado). Universidade Federal de Minas Gerais, Belo Horizonte. Retrieved in 2019, June 30, from http://csr.ufmg.br/modelagem/dissertacoes/ adilio.pdf

Paz, D. H. F. D., Lafayette, K. P. V., \& Sobral, M. D. C. (2018). GIS-based planning system for managing the flow of construction and demolition waste in Brazil. Waste Management \& Research, 36(6), 541-549. http://dx.doi.org/10.1177/0734242X18772096. PMid:29776320.

Rogers, D. S., \& Tibben-Lembke, R. S. (1999). Going backwards: reverse logistics trends and practices. Pittsburgh, PA: Reverse Logistics Executive Council. 
Rogers, D. S., \& Tibben-Lembke, R. (2001). An examination of reverse logistics practices. Journal of Business Logistics, 22(2), $129-148$. http://dx.doi.org/10.1002/j.2158-1592.2001.tb00007.x.

Roviriego, L. F. V. (2005). Proposta de uma metodologia para a avaliação de sistemas de coleta seletiva de resíduos sólidos domiciliares (Dissertação de mestrado). Universidade de São Paulo, São Carlos. Retrieved in 2019, June 30, from http://www.teses.usp.br/teses/ disponiveis/18/18137/tde-17022006-194345/pt-br.php

Santos, B. S., Santos, R. L., \& Santo, S. M. (2012, May). Análise espacial aplicada à expansão de condomínios fechados na cidade de Feira de Santana (BA). In Anais do $4^{\circ}$ Simpósio Brasileiro de Ciências Geodésicas e Tecnologias da Geoinformação. Recife: UFPE. Retrieved in 2019, June 30, from https://www.ufpe.br/cgtg/SIMGEOIV/CD/artigos/SIG/149_5.pdf

Sellitto, M. A. (2018). Reverse logistics activities in three companies of the process industry. Journal of Cleaner Production, 187, $923-$ 931. http://dx.doi.org/10.1016/j.jclepro.2018.03.262. 
Appendix A. Questionnaire about Styrofoam ${ }^{\circledR}$ consumption and disposal habits.

\section{QUESTIONNAIRE \\ CONSUMPTION OF STYROFOAM ${ }^{\circledR}$ PACKGING}

Personnal data

Age:

City of residence:

If lives in Florianópolis, in which neighborhood lives:

\section{Styrofoam ${ }^{\circledR}$ consumption}

How many food products with Styrofoam ${ }^{\circledR}$ packaging do you consume per week? (Fruits, greenery, meat)

1 don't consume.

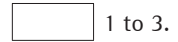

4 to 6.

7 or more.

How many Styrofoam ${ }^{\circledR}$ cups do you use per week? (For coffee, tea, juice)

1 don't consume.
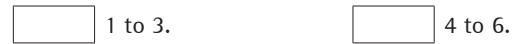

7 or more.

How many Styrofoam ${ }^{\circledR}$ vessels do you use to store meal per week?

1 don't consume.

1 to 3.

4 to 6.

7 or more.

Destination of the Styrofoam ${ }^{\circledast}$ waste

Do you recycle the Styrofoam ${ }^{\circledast}$ packaging of the products that you consume?

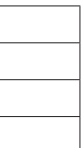

Yes, 1 recycle all the EPS packaging.

Yes, except the ones used to pack meat, because they are contaminated.

No, but 1 know it can be recycled.

No, 1 did not know that EPS is recyclable.

If there was the possibility to deliver the Styrofoam ${ }^{\circledR}$ waste in a specific place, such as a Voluntary Delivery Point (VDP), would you do it?

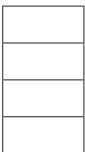

Yes, always.

Yes, whenever it would be possible, otherwise, 1 would discard it with the recyclables at home.

No, because 1 do not believe it would be practical.

No, because 1 do not see advantages in doing so.

Did you know that around 98\% of Styrofoam ${ }^{\circledR}$ is air? The main barrier of its recycling is transportation, and it occupies a significant space until it is viable for recycling it. However, most of the time, it is discarded with regular waste and ends up in landfills. There EPS waste occupies too much space, compromising the lifespan of the landfill. One simple action could help to reduce the impacts caused by EPS when it arrives in the environment, to transform it into new products, such as bricks and skirtings, or even become a packaging again. This information makes you rethink about delivering Styrofoam ${ }^{\circledR}$ waste in a specific place, like a VDP, for example?

Yes, 1 would deliver the Styrofoam ${ }^{\circledast}$ packaging in a VDP

1 am still not sure, but this information made me rethink about it.

No, this information did not make me change my mind. 